\title{
Partial Enhancement of Hyprethermia-induced Apoptosis by Increasing Enzymatic Activity of Thymidine Phosphorylase in Human Gastric Carcinoma Cell Lines
}

\author{
Akira Goto ${ }^{1}$, Mitsuhiko Osaki ${ }^{1}$, Hiroshi Kiyonari ${ }^{1}$ and Hisao Ito ${ }^{1}$ \\ ${ }^{1}$ First Department of Pathology Faculty of Medicine, Tottori University, 86 Nishi-cho, Yonago, Tottori 683-8503, JAPAN \\ (Received 18 January 1999; and accepted 14 February 1999)
}

\begin{abstract}
We examined the effects of hyperthermia and/or 5'-deoxy-5-fluorouridine (5'-DFUR) on the induction of apoptosis of three human gastric cancer cell lines, MKN-1 (carrying mutated p53), TMK-1 (mutated) and MKN-74 (wild-type), by comparision with the expression of thymidine phosphorylase (dThdPase) which converts 5'-DFUR to 5-fluorouracil (5-FU). The expression level of dThdPase was higher in TMK-1, lower in MKN-74, and absent in MKN-1. The enzymatic activity was up-regulated by hyperthermia $\left(44^{\circ} \mathrm{C}\right.$ for $\left.30 \mathrm{~min}\right)$ in the former two, but not in MKN-1. Hyperthermia or 5'-DFUR gradually induced apoptosis in MKN-74 and TMK-1, the value of the apoptotic index (AI: percentage of apoptotic cells) at $48 \mathrm{~h}$ was higher by treatment with hyperthermia than by 5'-DFUR. Sequential treatment with hyperthermia and 5'-DFUR markedly enhanced induction of apoptosis in both MKN-74 and TMK-1, with values of $\mathrm{AI}$ at $48 \mathrm{~h}$ being $31.4 \%$ and $54.8 \%$, respectively. Flow cytometric analysis revealed increased sub G1 fraction in both MKN-74 and TMK-1, and cell arrest in G2/M in MKN-1, which was resistant to the apoptosis induced by the hyperthermia and/or 5'-DFUR. These results indicated that the sequential treatment with hyperthermia and 5'-DFUR enhanced the induction of apoptosis, which might partially be correlated with dThdPase expression.
\end{abstract}

Thymidine phosphorylase (dThdPase), a member of the pyrimidine nucleoside phosphorylase (PyNPase) family, catalyzes the reversible phosphrolysis of thymidine, and converts 5'-deoxy-5fluorouridine (5'-DFUR) to 5-fluorouracil (5FU) $(1,8,22,27)$. dThdPase is identical to platelet-derived endothelial cell growth factor (PD-ECGF), which has potent angiogenic activity in vivo and in vitro $(4,7,33)$. It has been demonstrated that the expression level is higher in tumor tissue than in corresponding normal tissue in a variety of human tumors $(17,20,23,26,28-$

Correspondence and reprint requests to: Dr Hisao Ito at above adress. Tel: +81-859-34-8015; Fax: +81859-34-8273. e-mail: ito@grape.med. tottori-u. ac.jp
32). Higher levels of expression of dThdPase are well known to be correlated with poorer prognosis in patients with gastric, pancreatic and colonic carcinomas. For example, Maeda et al. examined 120 gastric carcinomas and found that higher dThdPase expression was significantly correlated with increases in intratumoral microvessel density and hepatic metastasis (17).

In turn, gastric carcinoma is one of the most frequent malignancies in Japan and other countries. Although the incidence is becoming lower, the disease is still responsible for a significant number of deaths per annum in Japan. Surgical treatment is undoubtedly the first choice for treatment of gastric cancer patients. Hyperthermia is well known to induce apoptosis in various cancer 
cells in vivo and in vitro $(5,10,16)$. Hyperthermic peritoneal perfusion (HPP) combined with anticancer therapy has been also conducted in cases with advanced gastric carcinoma in an attempt to reduce the tumor size and improve prognosis. Kaibara et al. analyzed patients with gastric cancer showing subserosa infiltration, and reported 10-year survival rate in patients receiving HPP was better than that in the other patients without HPP, although this was not statistically significant $(9,11)$. Thus, the applicability of HPP seems to be limited for treatment of advanced gastric carcinoma.

Recently, we confirmed that human gastric carcinoma cell lines underwent apoptosis following short-term hyperthermia, in contrast to the necrosis induced by long-term hyperthermia (3). Hyperthermia-induced apoptosis of gastric cancer cells occurred in both p53 gene-dependent and -independent manners, accompanied by the expression of heat shock protein 70 (3). In this study, we examined the role of dThdPase in hyperthermia-induced apoptosis. Our results provided useful information regarding the relationship between hyperthermia and dThdPase expression or its enzymatic activity in the induction of apoptosis of human gastric carcinoma.

\section{MATERIALS AND METHODS}

\section{Cell Lines}

We examined three cell lines derived from human gastric cancer, MKN-1, MKN-74 and TMK-1 (6, $21,24)$. MKN-1 was established from an adenosquamous cell carcinoma carrying a mutant p53 gene. MKN-74 is a well-differentiated tubular adenocarcinoma carrying the wild-type p53 gene. TMK-1 is a poorly differentiated adenocarcinoma carrying a mutant p53 gene. All the cell lines were cultured in RPMI 1640 (Cosmo Bio, Tokyo) containing $10 \%$ fetal bovine serum, $2 \mathrm{mM}$ glutamine and $100 \mathrm{U} / \mathrm{mL}$ penicillin in a humidified $5 \% \mathrm{CO}_{2}$ incubator at $37^{\circ} \mathrm{C}$. Cells were passaged twice weekly and routinely examined for mycoplasma contamination.

\section{Western Blotting for Endogenous dThdPase}

Before or after heat treatment at $44^{\circ} \mathrm{C}$ for $30 \mathrm{~min}$, the cells were trypsinized, washed in phosphatebuffered saline (PBS) and solubilized in lysis buffer $(50 \mathrm{mM}$ Tris- $\mathrm{HCl}$ pH 7.4, $125 \mathrm{mM} \mathrm{NaCl}$, $0.1 \%$ NP-40, $5 \mathrm{mM} \mathrm{NaF}, 1 \mathrm{mM}$ PMSF, $1 \mathrm{ng} / \mathrm{mL}$ leupeptin, $10 \mathrm{ng} / \mathrm{mL}$ soybean trypsin inhibitor, 1 $\mathrm{ng} / \mathrm{mL}$ aprotinin, $10 \mathrm{ng} / \mathrm{mL}$ n-tosyl-1phenylalanyl chloromethyl ketone) for $60 \mathrm{~min}$ on ice. Lysates were centrifuged at 2,500 $\mathrm{g}$ for $5 \mathrm{~min}$. Protein concentrations were determined by the Bradford protein assay (Bio-Rad. Lab., Richmond, CA) using bovine serum albumin as the standard. Aliquots of $30 \mu \mathrm{g}$ of protein were resolved by electrophoresis on $12 \%$ polyacrylamide gels, electrotransferred to polyvinylidene difluoride filters (Millipore, Bedford, MA), and blotted with mouse monoclonal antibody to dThdPase (1:500; obtained from Nippon Roche Research Center, Kanagawa, Japan). Blots were developed with peroxidaselabeled anti-mouse IgG (1:1000; MBL Co., Nagoya, Japan) using enhanced chemiluminescence (ECL Detection System; Amersham, Bucks, UK).

\section{dThdPase Enzyme Assay}

Cultured cells were collected and sonicated in 10 $\mathrm{mM}$ Tris- $\mathrm{HCl}$ buffer ( $\mathrm{pH} 7.4$ ) containing $15 \mathrm{mM}$ $\mathrm{NaCl}, 1.5 \mathrm{mM} \mathrm{MgCl}_{2}$ and $50 \mu \mathrm{M}$ potassium phosphate. This solution was then centrifuged at $105,000 \mathrm{~g}$ for $90 \mathrm{~min}$. The supernatant was dialyzed overnight against $20 \mathrm{mM}$ potassium phosphate buffer (pH 7.4) and $1 \mathrm{mM} \beta$ mercaptoethanol and was used as a source of crude dThdPase. The protein concentration was determined by the method of Lowry et al. (15). All procedures were performed at $4^{\circ} \mathrm{C}$. The reaction mixture $(120 \mu \mathrm{L})$ for the enzyme-activity assay contained $183 \mathrm{mM}$ potassium phosphate ( $\mathrm{pH}$ 7.4), $10 \mathrm{mM}$ 5'-DFUR, and the crude enzyme from human cells. The reaction was performed at $37^{\circ} \mathrm{C}$ for $60 \mathrm{~min}$ and was then terminated by the addition of $360 \mu \mathrm{L}$ methanol. After removal of the precipitate by centrifugation, an aliquot of the reaction mixture $(100 \mu \mathrm{L})$ was added to $20 \mu \mathrm{M}$ 5-chlorouracil as an internal standard and then applied to the high-performance liquid chromatography (HPLC) column (ERC-ODS-1171). The solvent system used was $50 \mathrm{mM}$ sodium phosphate buffer ( $\mathrm{pH} 6.8$ ) containing $5 \mathrm{mM}$ 1-decane sulfonic acid: methanol $(85: 15, \mathrm{v} / \mathrm{v})$. The amount of 5-FU produced was measured with a UV monitor $(280 \mathrm{~nm})$.

\section{Hyperthermia and 5'-DFUR Treatment}

Stock 5'-DFUR, obtained from Nippon Roche 
Research Center (Kanagawa, Japan), was dissolved in $50 \%$ dimethyl sulfoxide (DMSO) to a concentration of $10 \mathrm{mM}$ and diluted with medium to the desired experimental concentrations.

Approximately $1 \times 10^{5}$ cells were seeded in 50 $\mathrm{mL}$ flasks and incubated for $24 \mathrm{~h}$ at $37^{\circ} \mathrm{C}$. The medium was replaced with fresh medium heated to $44^{\circ} \mathrm{C}$ (Thermalrobo; iuchi Co., Japan) and the cells were maintained at $44^{\circ} \mathrm{C}$ for $30 \mathrm{~min}$ in a water bath. 5'-DFUR was added directly to the culture medium immediately after heat stress. Then, cells were transferred to a $37^{\circ} \mathrm{C}$ incubator.

\section{Cell Viability and Apoptotic Index (AI)}

After treatment, the cells were incubated at $37^{\circ} \mathrm{C}$ for 24,48 and $72 \mathrm{~h}$, then trypsinized and harvested. Cell viability was counted by trypan blue staining. Cultured cells were stained with $1 \mathrm{mg} /$ $\mathrm{mL}$ Hoechst 33258 for $15 \mathrm{~min}$ and analyzed by fluorescence microscopy (EFD-3; Nikon, Tokyo, Japan) with excitation at $360 \mathrm{~nm}$ to detect apoptosis. AI was defined as $\mathrm{AI}=$ apoptotic cells/ 200 cells $\times 100$.

\section{DNA Fragmentation}

The treated cells $\left(1 \times 10^{7}\right)$ were trypsinized, washed twice with PBS, and suspended in lysis buffer ( $10 \mathrm{mM}$ EDTA, $50 \mathrm{mM}$ Tris- $\mathrm{HCl} \mathrm{pH} 8.0$, $0.5 \%$ SDS and $0.5 \mathrm{mg} / \mathrm{mL}$ proteinase $\mathrm{K}$ ). After incubation overnight at $37^{\circ} \mathrm{C}$, DNA was extracted with phenol/chloroform and precipitated with isopropanol according to standard protocols. Finally, after RNase treatment, DNA was dissolved in Tris-EDTA (TE) buffer. Aliquots of 10 $\mu \mathrm{g}$ of DNA were subjected to electrophoresis on $2 \%$ agarose gels, incubated in $2 \mu \mathrm{g} / \mathrm{mL}$ ethidium bromide and visualized under ultraviolet (UV) illumination.

\section{Flow Cytometric Analysis}

The treated cells were fixed with $70 \%$ ethanol for more than $4 \mathrm{~h}$ at $4^{\circ} \mathrm{C}$. The ethanol was removed and cells were solubilized in citrate-phosphate buffer for $30 \mathrm{~min}$ at room temperature. Next, the cells were added to PBS and $10 \mathrm{mg} / \mathrm{mL}$ RNase (DNase free), and incubated for $30 \mathrm{~min}$ at $37^{\circ} \mathrm{C}$. Finally, the cells were resuspended in PBS and 1 $\mathrm{mg} / \mathrm{mL}$ propidium iodide (PI) for $30 \mathrm{~min}$ in the dark, then the nuclear DNA content was analyzed with a flow cytometer (FCS-1; Japan Spectros- copic Co., Tokyo, Japan), and $1 \times 10^{4}$ cells were examined in each sample.

\section{RESULTS}

First, we analyzed the expression of dThdPase and its enzymatic activity. Western blotting analysis revealed a higher level of expression of dThdPase in TMK-1, and a lower level in MKN74 (Fig. 1). No expression was detected in MKN1 (Fig. 1). Enzymatic activity of endogenous dThdPase before and after heat treatment was $107.2 \mathrm{unit} / \mathrm{mg}$ and $130.4 \mathrm{unit} / \mathrm{mg}$ in TMK-1, and $0.6 \mathrm{unit} / \mathrm{mg}$ and $1.4 \mathrm{unit} / \mathrm{mg}$ in MKN-74, respectively (Table 1). Although the heat treatment enhanced enzymatic activity, there was no statistical significance between the value before and after treatment in the both TMK-1 and MKN-74. No enzymatic activity was observed in MKN-1.

Next, we examined the effects of 5'-DFUR treatment $(10 \mathrm{mM})$, and/or hyperthermia $\left(44^{\circ} \mathrm{C}\right.$ for $30 \mathrm{~min}$ ) on the induction of apoptosis in the three cell lines. Hoechst 33258 staining confirmed a gradual increase in number of apoptotic cells (Fig. 2A, B). DNA ladder formation was detected on agarose gels in TMK-1 and MKN-74 (Fig. 2C), but not MKN-1. At $48 \mathrm{~h}$ after treatment, AI was higher with hyperthermia than with 5'DFUR treatment in MKN-1 and TMK-1, but not MKN-1 which did not undergo apoptosis (Fig. 3 ). The induction of apoptosis was markedly enhanced by hyperthermia followed by 5'-DFUR treatment in all the three lines (Fig. 3). AI with

Table 1 Enzymatic activity of endogeneous dThdPase ${ }^{a}$

\begin{tabular}{lcc}
\hline & \multicolumn{2}{c}{ Heat treatment(unit/mg) } \\
Cell lines & Before & After \\
\hline MKN-1 & N.D. & N.D. \\
MKN-74 & $0.6 \pm 0.0$ & $1.4 \pm 0.2$ \\
TMK-1 & $107.2 \pm 74.7$ & $130.4 \pm 90.7$ \\
\hline
\end{tabular}

${ }^{a} \mathrm{~d}$ ThdPase enzyme assay is determined as described in materials and methods.

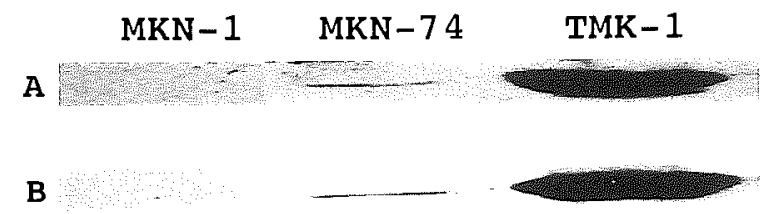

Fig. 1 Expression of endogenous dThdPase determined by Western blotting before $\left(37^{\circ} \mathrm{C}\right.$; A) or after $\left(44^{\circ} \mathrm{C}\right.$; B) treatment. 
A

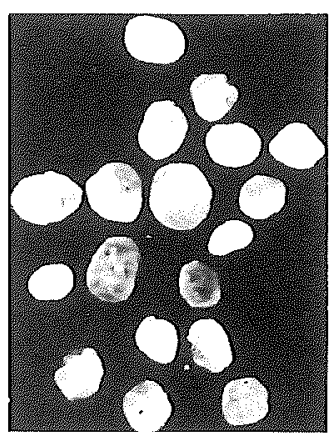

B

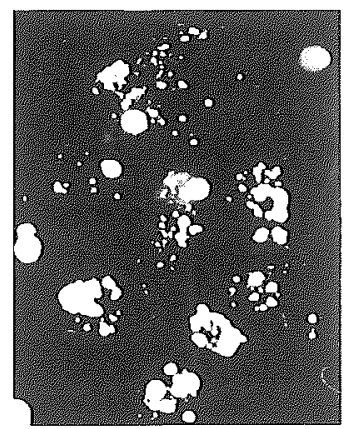

C

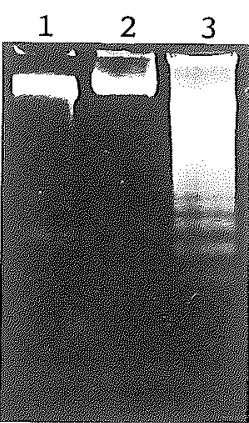

Fig. 2 Morphological analysis of untreated TMK -1 cells $(A, \times 400)$ or at $48 \mathrm{~h}$ after combined treatment $(B, \times$ 400). Cells were stained with Hoechst33258. Cells with fragmented nuclei corresponding to apoptotic cells are noted. (C) Detection of DNA ladder formation on agarose gel electrophoresis in untreated MKN-74 cells (Lane 2) or at $48 \mathrm{~h}$ after combined treatment (Lane 3). A 123-bp DNA ladder molecular weight standard was run in Lane 1.

the 5'-DFUR treatment, hyperthermia and sequential treatment with both was $3.9 \%, 13.7 \%$ and $54.8 \%$ in TMK-1, and $7.3 \%, 17.8 \%$ and $31.4 \%$ in MKN-74, and $1.1 \%, 2.5 \%$ and $4.1 \%$ in MKN-1. Thus, TMK-1 showed the strongest response among the three cell lines in the induction of apoptosis by sequential treatment with hyperthermia and 5'-DFUR.

Fig. 4 shows cell viability and AI after sequential treatment with hyperthermia and 5'-DFUR in the three cell lines. Cell viability gradually decreased reaching approximately $20 \%$ in TMK-1, $60 \%$ in MKN-74, and 70\% in MKN-1. AI gradually increased in TMK-1, in which approximately

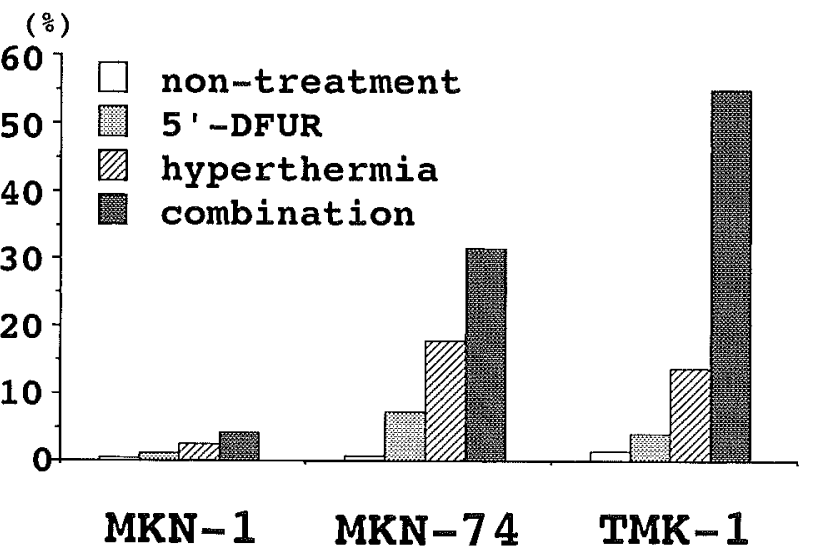

Fig. 3 Combined treatment, treatment of 5'DFUR alone or hyperthermia alone-induced apoptotic indices at $48 \mathrm{~h}$ after treatment in human gastric cancer cell lines. Apoptotic index was determined as described in Materials and Methods. Data are average values of three independent experiments.
$65 \%$ of the cells showed apoptosis at $72 \mathrm{~h}$ after treatment. AI became slightly lower at $72 \mathrm{~h}$ than at $48 \mathrm{~h}$ in MKN-74, indicating that a few
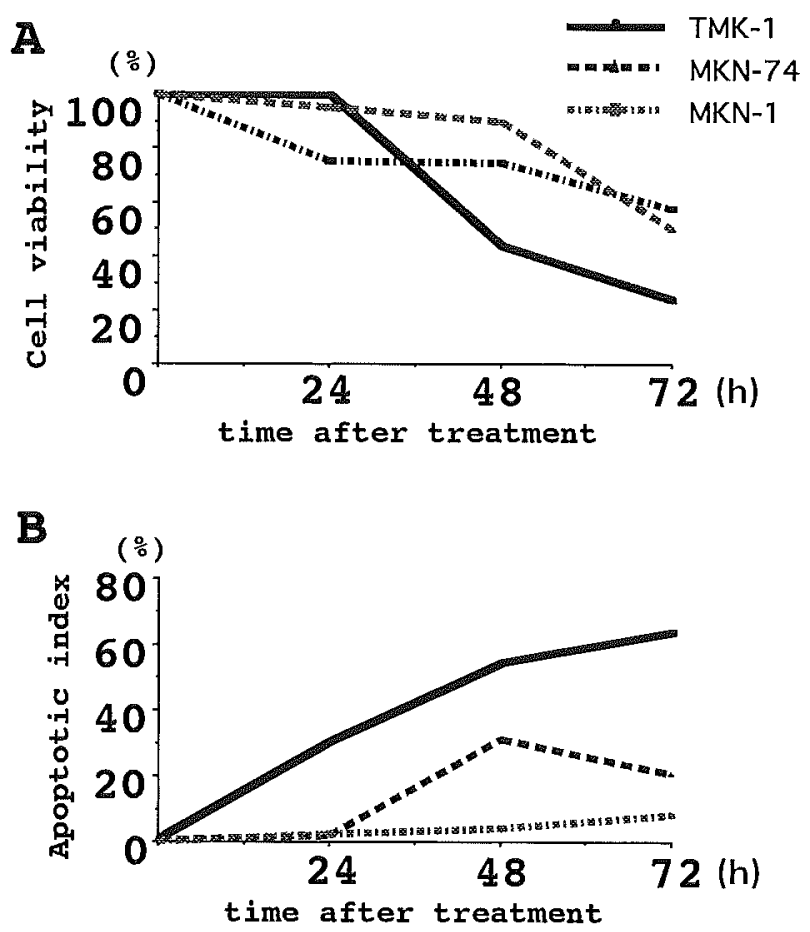

Fig. 4 Combined treatment-induced survival alteration (A) and -induced apoptotic indices (B) in human gastric cancer cell lines. Cells were treated at $44^{\circ} \mathrm{C}$ for $30 \mathrm{~min}, 1 \mathrm{mM} 5^{\prime}$-DFUR was added and harvested after 24,48 or $72 \mathrm{~h}$. Alterations in survival and apoptotic index were determined as described in Materials and Methods. Data are average values of three independent experiments. 
apoptotic cells with fragmented nuclei might have been completely destroy. Sequential treatment was less effective in MKN-1, in which flow cytometric analysis demonstrated a decrease in Gl fraction and increases in $\mathrm{S}$ and $\mathrm{G} 2 / \mathrm{M}$ fractions at 24 and 48 hours after treatment, followed by a decrease in the $\mathrm{G} 2 / \mathrm{M}$ fraction (Fig. 5). On the other hand, the sub G1 fraction, corresponding to apoptotic cells, increased from $24 \mathrm{~h}$ after treatment in TMK-1 (Fig. 5).

\section{DISCUSSION}

We induced apoptosis with 5'-DFUR, hyperthermia and sequential treatment with both in three human gastric carcinoma cell lines. The susceptibility of these cell lines to the treatment was obviously variable. Apoptosis of TMK-1 and MKN-74 was confirmed not only by morphological analysis, but also by detection of DNA ladder formation on agarose gels. Following combination treatment, however, MKN-1 showed cell cycle arrest, but not obvious apoptosis. This might be partially explained by a total absence of dThdPase expression in MKN-I, while the reason for the hyperthermia-resistance of the cells remains unclear.

Paradoxically, repeated experiments always revealed lower mean AI at $48 \mathrm{~h}$ than at $72 \mathrm{~h}$ with sequential treatment in MKN-74. This might have been due to complete destruction of the cells, resulting in nuclear dust which is readily diffusible and could not be counted as apoptotic cells by Hoechst staining. Therefore, it is feasible that mean AI might be higher than the value demonstrated in this study.

AI was rather higher in MKN-74 than in TMK-1 following treatment with 5'-DFUR or hyperthermia. Combination treatment, however, obviously enhanced apoptosis in TMK-1. This might partially be explained by the far higher expression of dThdPase and its enzymatic activity in TMK-1 than in MKN-74. In fact, heat treatment up-regulated dThdPase enzymatic activity in both cell lines. These findings suggested the clinical efficacy of hyperthermia as a therapeutic tool for at least some forms of gastric carcinoma. In other words, the effect of hyperthermia is not

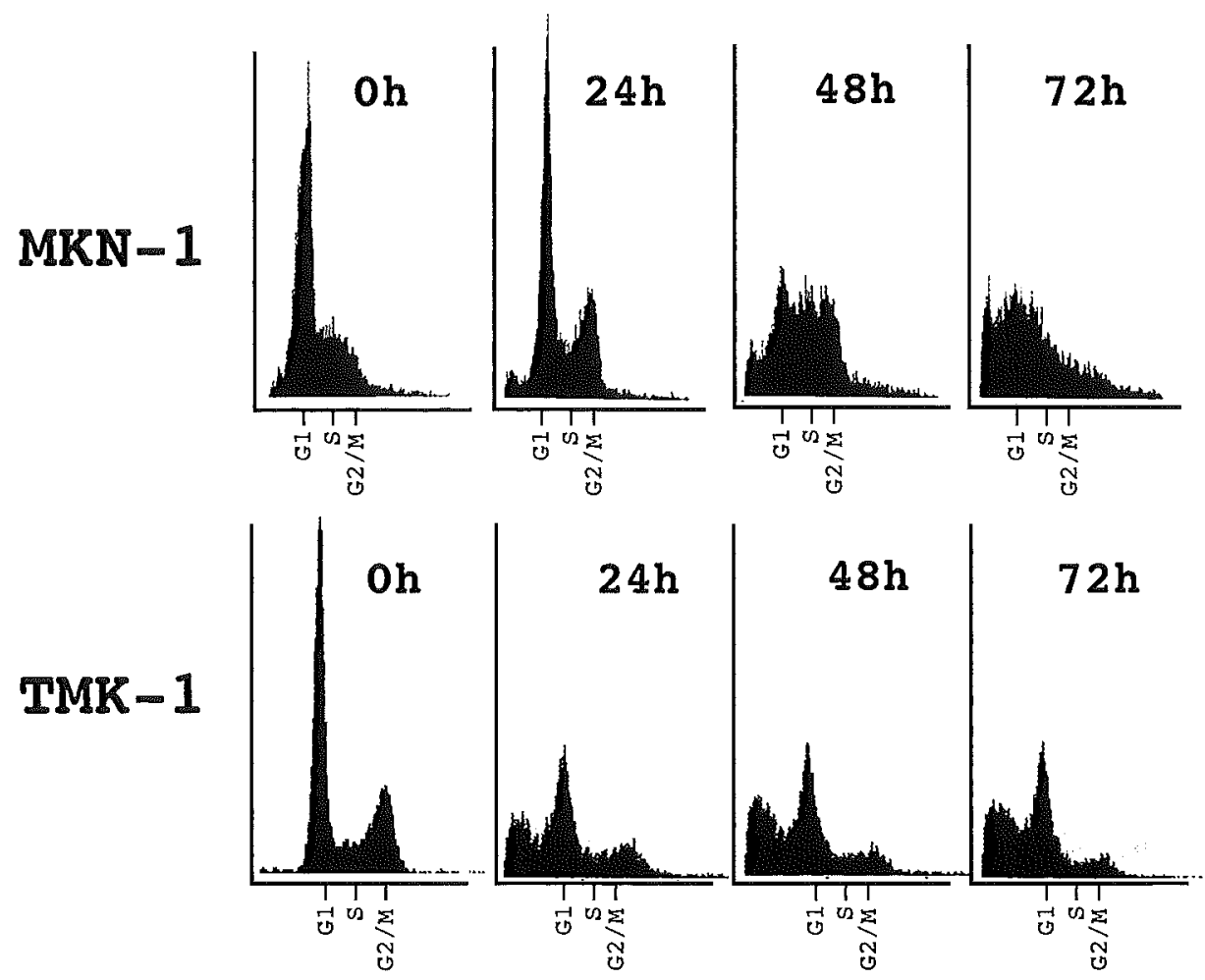

Fig. 5 Flow cytometric analysis in MKN-1 and TMK-1 cells. After combined treatment, the cells were incubated at $37^{\circ} \mathrm{C}$ for 24,48 or $72 \mathrm{~h}$ and harvested. Flow cytometric analysis was performed as described in Materials and Methods. 
necessarily constant and not to be expected in all gastric carcinomas.

In contrast to the sequential treatment, 5'DFUR induced apoptosis more effectively in MKN-74 than in TMK-1, despite the considerably lower expression levels of dThdPase and also lower enzymatic activity in the former. The differences in susceptibility to 5'-DFUR may have been due to the direct cytotoxic effect of 5'-DFUR and chemosensitivity of the cell lines, which might depend on genetic alterations, especially in p53 gene status. We found no previous reports concerning the direct effects of 5'-DFUR for cultured cancer cell lines. Although dThdPase converts 5'-DFUR to 5-FU which exerts cytotoxic effects, our study did not exclude the possibility that 5'-DFUR also acts as a cytotoxic agent.

There is now considerable evidence to suggest that chemosensitivity is affected by genetic alterations, especially p53 gene status $(13,14)$. In fact, cancer cells carrying mutated (mt) p53 are known to be more resistant to 5-FU than cells with wild-type (wt) p53. One of the roles of wt p53 is to sense DNA damage and either initiate repair or trigger the apoptotic pathway when there is a sufficient level of damage to the cells. We also demonstrated that 5-FU induced apoptosis in human gastric carcinoma cell lines, MKN-45 and MKN-74 carrying wild-type p53 gene, but not in MKN-28 carrying a mutated p53 gene or KATOIII lacking the gene. Thus, higher susceptibility to the combined treatment might be affected by p53 gene status. Enhancement of apoptosis in MKN74 might occur predominantly via a p53 genedependent pathway.

Lenz et al. (12) reported that colorectal cancers with wt p53 had significantly lower levels of thymidylate synthase (TS), the only de novo source of thymidine in cells, compared to cancer with $\mathrm{mt} \mathrm{p} 53$. They suggested a regulatory relationship between p53 and TS. In fact, it has been shown that TS protein binds to p53 mRNA, supporting a possible regulatory connection (2). This is comparable, in part, with the lower level of expression of dThdPase observed in MKN-74 carrying wt p53 than in TMK-1 carrying mt p53. The apoptosis-resistant nature of $\mathrm{MKN}-1$, as described above, might be partially explained by $\mathrm{mt}$ p53. Recently, it was demonstrated that transcriptional activity of $\mathrm{mt} \mathrm{p} 53$ was dependent on the site of the mutated codon $(18,25)$. Mutations have been confirmed at codons 143 and 147 in MKN-1, and 173 in TMK-1. This might reflect the different responses to the treatment in the induction of apoptosis.

Miyadera et al. (19) recently found a potent inhibitor of dThdPase, TPI, which has been shown to suppress proliferation of the xenotransplanted TMK-1 into nude-mice. Valuable information on the mechanism of the hyperthermiainduced apoptosis might be obtained by analyzing the cell lines treated with TPI, which awaits further investigation.

\section{ACKNOWLEDGMENTS}

We wish to thank Dr Nariyuki Yamane and Dr Tetsuya Taniguchi of the first Department of Surgery and $\mathrm{Mr}$ Norihisa ITAKI of the Department of Pathology, Tottori University for their helpful discussions, skillful technical assistance and photographic work.

This work was supported in part by a Grant-inAid from the Ministry of Education, Science, Sport and Culture of Japan.

\section{REFERENCE}

1. AkiYama S. (1993) [Molecular basis for resistance to anticancer agents and reversal of the resistance]. Human Cell 6, 1-6. (in Japanese).

2. Chu E., Copur S., Jones K. L., Khleif S., Voeller D., Maley G. F, Maley F. and Allegra C. J. (1995) Thymidylate synthase regulates the translation of p53 mRNA. Proc. Am. Assoc. Cancer Res. (Abstract) 36, 563.

3. Goto A., Shomori K., Ohkumo T., Tanaka F., Sato K. and ITo H. (1999) Hyperthermia-induced apoptosis occurs in both a 53 gene dependent and an independent manner in three human gastric carcinoma cell lines. Oncology Reports 6, 335-339.

4. Haraguchi M., Furukawa T., Sumizana T. and Akiyama S. (1993) Sensitivity of human KB cells expressing plateletderived endothelial cell growth factor to pyrimidine antimetabolites. Cancer Res. 53, 5680-5682.

5. Henderson B. W., Waldow S. M., Potter W. R. and DovgheRTY T. J. (1985) Interaction of photodynamic therapy and hyperthermia: tumor response and cell survival studies after treatment of mice in vivo. Cancer Res. 45, 6071-6077.

6. HoJo H. (1977) Establishment of cultured cell lines of human stomach cancer origin and their morphological characteristics. Niigata Igakukai Zasshi 91, 737-752. (in Japanese).

7. Igarashi M., Dhar D. K., Kubota H., Yamamoto A., El A. O. and Nagasue N. (1998) The prognostic significance of microvessel density and thymidine phosphorylase expression in squamous cell carcinoma of the esophagus. Cancer 82, 1225-1232.

8. Ishitsuka H., Miwa M., Takemoto K., Fukuoka K., Itoga A. and Maruyama H. B. (1980) Role of uridine phosphorylase for antitumor activity of 5'-deoxy-5-fluorouridine. Gann 71, 112-123. 
9. Kaibara N., Hamazoe R., Itsuma Y., Maeta M. and KOGA S. (1989) Hyperthermic peritoneal perfusion combined with anticancer chemotherapy as prophylactic treatment of peritoneal recurrence of gastric cancer. Hepatogastroenterology 36, 75-78.

10. Kang M. S., Song C. W. and Levitt S. H. (1980) Role of vascular function in response of tumors in vivo to hyperthermia. Cancer Res. 40, 1130-1135.

11. Koga S., Hamazoe R., Maeta M., Shimizu N., Murakami A. and Wakatsukı T. (1988) Prophylactic therapy for peritoneal recurrence of gastric cancer by continuous hyperthermic peritoneal perfusion with mitomycin $C$. Cancer 61, 232-237.

12. Lenz H. J., Hayashi K., Salonga D., Danenberg K. D., Danenberg P. V., Metzger R., Banerjee D., Bertino J. R., Groshen S., Leichman L. P. and Leichman C. G. (1998) p53 point mutations and thymidylate synthase messenger RNA levels in disseminated colorectal cancer: an analysis of response and survival. Clin Cancer Res. 4, 1243-1250.

13. Lowe S. W., Ruley H. E., Jacks T. and Housman D. E. (1993) p53-dependent apoptosis modulates the cytotoxicity of anticancer agents. Cell 74, 957-967.

14. Lowe S. W., Bodis S., McClatchey A., Remington L., Ruley H. E., Fisher D. E., Housman D. E. and Jacks T. (1994) p53 status and the efficacy of cancer therapy in vivo. Science 266, 807-810.

15. Lowry O. H., Rosebrough N. J., Farr A. L. and Randall R. J. (1951) Protein measurement with the Folin phenol reagent. J. Biol. Chem. 193, 265-275.

16. Lyons J. C., Ross B. D. and Song C. W. (1993) Enhancement of hyperthermia effect in vivo by amiloride and DIDS. Int. J. Radiat. Oncol. Biol. Phys. 25, 95-103.

17. Maeda K., Chung Y. S., Ogaiva Y., Takatsuka S., Kang S. M., Ogaiva M., Sawada T., Onoda N., Kato Y. and Sowa M. (1996) Thymidine phosphorylase/plateletderived endothelial cell growth factor expression associated with hepatic metastasis in gastric carcinoma. $B r . J$. Cancer 73, 884-888.

18. Miller C. W., Chumakov A., Said J., Chen D. L., Aslo A. and Koeffler H. P. (1993) Mutant p53 proteins have diverse intracellular abilities to oligomerize and activate transcription. Oncogene 8, 1815-1824.

19. Miyadera K., Emura T., Suzuki N., Akiyama S., Fukushima M. and Yamada Y. (1998) Novel fanctional antitumor nucleoside TAS-102, combined form of F3dThd and its modulator (2) : Inhibitory effect of TPI on tumorderived angiogenesis and metastasis. 89th Annual Meeting of the American Association for Cancer Research, March 28-April 1, 1998, New Orleans, USA, Proceeding of the American Association for Cancer Research 39, 609.

20. Moghaddan A., Zhang H. T., Fan T. P., Hu D. E., Lees V. C., Turley H., Fox S. B., Gatter K. C., Harris A. L. and Bicknel. R. (1995) Thymidine phosphorylase is angiogenic and promotes tumor growth. Proc. Natl. Acad. Sci. US A 92, 998-1002.

21. Motorama T, Hojo H. and Suzuki T. (1979) Evaluation of the regrowth assay method as an in vitro drug sensitivity test and its application to cultured cell lines. Acta Med. Biol. 27, 49-63.

22. Nio Y., Kimura H., Tsubono M., Tseng C. C., Kainabata K., Masal Y., Hayashi H., Meyer C., Fukumoto M. and Tobe T. (1992) Antitumor activity of 5'-deoxy-5- fluorouridine in human digestive organ cancer xenografts and pyrimidine nucleoside phosphorylase activity in normal and neoplastic tissues from human digestive organs. Anticancer Res. 12, 1141-1146.

23. O’Brien T., Cranston D., Fuggle S., Bicknell R. and HARRIS A. L. (1995) Different angiogenic pathways characterize superficial and invasive bladder cancer. Cancer Res. 55, 510-513.

24. Ochial A., Yokozaki H., Kyo E., Hozumi T. and Tahara E. (1985) A monoclonal antibody reacting with various human carcinomas and fetal colon and esophagus. Jpn. $J$. Cancer Res. 76, 915-918.

25. Park D. J., Nakamura H., Chumakov A. M., Said J. W., Miller C. W. Chen D. L. and Koeffler H. P. (1994) Transactivational and DNA binding abilities of endogenous p53 in p53 mutant cell lines. Oncogene 9, 18991906.

26. Reynolds K., Farzaneh F., Collins W. P., Campbell S., Bourne T. H., Lawton F., Moghaddam A., Harris A. L. and Bicknel. R. (1994) Association of ovarian malignancy with expression of platelet-derived endothelial cell growth factor. J. Natl. Cancer Inst. 86, 1234-1238.

27. Satoh B., Ohtoshi M., Ishida Y., Henmi, K., Kaneko I., Soda M., Suglhara J., Shibagaki F., Iwai N., Nakamura T., Yamasakı T. and Matsumoto S. (1998) [Correlation between pyrimidine nucleoside phosphorylase (PyNPase)/thymidine phosphorylase/platelet-derived endothelial cell growth factor and histological prognostic factor, and influence of 5'-deoxy-5-fluorouridine (5'DFUR) administration on PyNPase activities and serum immunosuppressive acidic protein levels. A study group of oral anti-cancer drugs in Seiban/Tajima area]. Gan To Kagaku Ryoho 25, 359-364. (in Japanese).

28. Takahashi Y., Bucana C. D., Liu W., Yoneda J., Kitadal Y., Cleary K. R. and Ellis L. M. (1996) Platelet-derived endothelial cell growth factor in human colon cancer angiogenesis: role of infiltrating cells. J. Natl. Cancer Inst. 88, 1146-1151.

29. Takebayashi Y., Yamada K., Miyadera K., Sumizawa T., Furukaiva T., Kinoshita F., AOKl D., Okumura H., Yamada Y., AkiYama S. and Aikou T. (1996) The activity and expression of thymidine phosphorylase in human solid tumours. Eur. J. Cancer 32A, 1227-1232.

30. Takebayashi Y., Akiyama S., Akiba S., Yamada K., Miyadera K., Sumizaiva T., Yamada Y., Murata F. and AIKou T. (1996) Clinicopathologic and prognostic significance of an angiogenic factor, thymidine phosphorylase, in human colorectal carcinoma. J. Natl. Cancer Inst. 88, $1110-1117$.

31. Takebayashi Y., MiYadera K., Akiyama S., Hokita S., Yamada K., Akiba S., Yamada Y., Sumizawa T. and Aikou T. (1996) Expression of thymidine phosphorylase in human gastric carcinoma. Jpn. J. Cancer Res. 87, 288295.

32. Tol M., Hoshina S., Taniguchi T., Yamamoto Y., Ishitsuka H. and Tominaga T. (1995) Expression of platelet-derived endothelial cell growth factor/thymidine phosphorylase in human breast cancer. Int. J. Cancer 64, 79-82.

33. Ueda M., Ueki K., Kumagal K., Teral Y., Okamoto Y., UeKI M. and OTSUKI Y. (1998) Apoptosis and tumor angiogenesis in cervical cancer after preoperative chemotherapy. Cancer Res. 58, 2343-2346. 